\title{
Voorzienigheid en verantwoordelijkheid
}

\author{
A. van de Beek \\ Faculteit Godgeleerdheid \\ Vrije Universiteit \\ Amsterdam \\ NEDERLAND \\ E-pos: a.van.de.beek@th.vu.nl
}

\section{Abstract}

\section{Providence and responsibility}

Providence is usually regarded as a theological concept that sets human hearts at rest. God rules our lives, and in particular those of Christians. Modern people often have problems with this idea. How can a good God rule a world with diseases and disasters? And can we actually imagine such an all-controlling power? Nevertheless, these are not the real issues concerning the concept of providence. The existential problem is that providence in the Bible has to do with responsibility: God takes responsibility for his world. This responsibility is total; it even implies responsibility and punishment for sin. Thus providence and atonement are not two separated fields of theology, but coincide. The chapter in the Bible to which the concept is originally related makes this plain: Genesis 22, and verse 8 in particular, states, "God himself will provide the lamb for the burnt offering, my son". (The Vulgate reads: "the victim for the holocaust".) In Genesis 16-22 the word "to provide", literally "to see" (r'h), turns out to be a key concept. Who sees? The Lord sees, Abraham sees and Hagar sees - and it is always in a situation of life and death in which they are called to responsibility to save lives. But actually these are lives that have already been sacrificed. Thus providence demands the ultimate from human beings, as it asks the ultimate from their God. Noordmans highlights this in a meditation on Matthew 6:34: "Jesus does not say this in order to lay worries to rest but in order to raise worries". If you search for the kingship of God, all things that are needed will be given to you - such as feet to walk the second mile. 


\section{Voorzienigheid}

Voorzienigheid speelt in de gereformeerde theologie een belangrijke rol. De bekendste formulering daarvan vinden we in zondag 10 van de Heidelbergse Catechismus:

Wat verstaat gij door de voorzienigheid van God? Antwoord: De almachtige en alomtegenwoordige kracht Gods door welke Hij hemel en aarde mitsgaders alle schepselen gelijk als met zijn hand nog onderhoudt en alzo regeert, dat loof en gras, regen en droogte, vruchtbare en onvruchtbare jaren, spijze en drank, gezondheid en krankheid, rijkdom en armoede en alle dingen niet bij geval, maar van zijn vaderlijke hand ons toekomen.

Voorzienigheid betekent dat God heel ons leven leidt. De catechismus spreekt over Gods vaderhand, maar meestal wordt met voorzienigheid niet bedoeld dat de zorg van God beperkt zou zijn tot de gelovigen, maar dat $\mathrm{Hij}$ alles leidt. Hij doet het regenen over rechtvaardigen en onrechtvaardigen (Matt. 5:45). Alles gebeurt volgens zijn wil. Zelfs geen haar valt van mijn hoofd zonder dat God het wil (Matt. 10:30). Dat reikt zelfs verder dan de mensenwereld: er valt zonder God ook geen musje van het dak (Matt. 10:29).

De voorzienigheid van God wordt daarom gewoonlijk behandeld in de scheppingsleer. Sommigen gaan daarin zover dat zij de voorzienigheid zien als creatio continua (zie bijvoorbeeld Moltmann, 1985:215-220). De klassieke gereformeerde theologie heeft zich daar steeds tegen verzet. Want de schepping heeft een eigen bestaan naast en tegenover God. Er is werkelijk iets uit Gods handen voortgekomen, toen Hij de aarde schiep. Weliswaar kan deze alleen blijven bestaan als God dat wil, maar dat is toch iets anders dan dat God voortdurend schept. Daarom wordt voorzienigheid verbonden met het begrip onderhouding (zie hierover uitvoerig Berkouwer, 1950:56-99). God onderhoudt van dag tot dag de wereld die Hij schiep. Hij laat de zon weer opgaan, Hij geeft regen en Hij houdt de sterren in hun baan. Hij zorgt ervoor dat mijn hart blijft kloppen en Hij laat mijn longen ademen. En als Hij daarmee ophoudt, dan houdt ook mijn leven op (Psalm 104:29).

Nu wordt voorzienigheid niet alleen verbonden met de onderhouding van de wereld. Een ander aspect is het koningschap van God (zie Berkouwer, 1950:100-150). God leidt de wereld niet om die altijd dezelfde te laten, maar Hij leidt die ergens naar toe. ${ }^{1}$ Heel de schepping staat ten

1 Door de sterke nadruk op Gods zorgend handelen gericht op de bestemming van de wereld die Berkouwer (1950) al aangeeft en nadien in de westerse theologie met haar nadruk op het Koninkrijk van God alleen maar toegenomen is, nadert deze positie dicht die van wat Moltmann wil zeggen met de creatio continua. 
dienste van God opdat zijn Koninkrijk zal komen. Daarheen wordt alles geleid. Nu vraagt het bereiken van een doel gewoonlijk een weg waarop geïnvesteerd moet worden en die het tegendeel lijkt te bereiken. Als ik mijn kamer opruim, wordt de rommel eerst alleen maar groter. Als een huis gerestaureerd wordt, wordt er eerst veel afgebroken. Zo is ook de weg van Gods koningschap dat Hij voorzien heeft voor de toekomst. 2 Ze loopt via afbraak van wat ons mensen belangrijk leek. Er worden duistere tunnels geboord in ons leven waar wij geen raad mee weten. Maar het is Gods voorzienigheid die iets beters op het oog heeft (vgl. Hebr. 11:40). Daarom mogen wij vertrouwen dat de dingen die wij nu niet begrijpen voor God zinvol zijn om zijn doel te bereiken (Calvijn, Institutie $\mathrm{I}, 17)$. Juist vanwege dit teleologische aspect van de voorzienigheid van God kunnen we ook de moeilijke dingen van het leven theologisch een plaats geven: ze dienen een hoger doel, ook als wij dat niet zien. Maar God heeft ze in zijn bestek wel in voorzien - niet alleen dat Hij van te voren wist dat het komen zou, maar ook dat het past in het doel dat Hij wil bereiken.

\section{Problematisch}

$\mathrm{Nu}$ is de voorzienigheid in de laatste eeuwen steeds meer problematisch geworden. Daarvoor worden twee redenen aangevoerd:

- De verbijsterende ervaringen van lijden (Berkouwer, 1950:21-23). Van Gennep (1989a:312-319) heeft gezegd, dat het onmogelijk is dat God ingrijpt in deze wereld, want dan had de holocaust nooit kunnen plaatsvinden. Er zijn dingen die gebeuren die God ook niet heeft gewild. 3 Je kunt toch niet zeggen dat de moord op de Joden uit Gods vaderhand is voortgekomen? Na de twintigste eeuw met zijn twee wereldoorlogen en al haar verdere verschrikkingen kunnen we niet meer geloven dat een almachtige goede God de geschiedenis leidt en dat alles dient tot een hoger doel. Want wat er gebeurd is in Verdun, in Auschwitz, in Ruanda en in Sierra Leone kan door geen enkel hoger doel gerechtvaardigd worden.

Deze gedachtegang is niet nieuw. De moderne theodiceediscussie is met name door Leibniz op gang gebracht (Leibniz, 1710). Dat was naar aanleiding van de aardbeving in Lissabon in 1755, waarbij duizenden mensen omkwamen. Het meest cynische was dat het op

2 Vergelijk Van Ruler (1972:32-45) die stelt dat God ook in het chaotische is en dat zelf schept.

3 Kushner (1987:48-61) stelt bijvoorbeeld dat het kwade er gewoon is. Het heeft niets met God te maken, maar het is een lot dat ons treft. Men vergelijke hiermee het felle verzet van Calvijn (Institutie 1,16,8) tegen fatum en fortuna. 
een zondagmorgen was en dat de meeste slachtoffers juist de mensen waren die in de kerken zaten. Hoe kon God nu zo iets doen? Leibniz probeert God te rechtvaardigen door te zeggen dat de wereld niet God is en dus begrensd is. Ze kan daarom per definitie niet perfect zijn. Aangezien God geen perfecte wereld kon scheppen, schiep Hij de best mogelijke wereld. In moderne vorm wordt dat theologisch gethematiseerd in de idee van de zelfontlediging van God. 4 God gaf aan de mens ruimte naast hemzelf en God gaf aan de mens vrijheid. Zo alleen kan de mens een antwoordelijk en daarmee verantwoordelijk schepsel wezen, zegt Hendrikus Berkhof (1973:191). Mensen zijn geen marionetten, maar personen die in vrijheid antwoorden op de roeping van God. ${ }^{5}$ God heeft daarmee bewust het risico gelopen dat ze verkeerd zouden kiezen.

- Daarmee zijn we al bij de tweede reden gekomen waarom voorzienigheid een omstreden theologoumenon is geworden: niet om God te rechtvaardigen, maar vanwege het belang van de menselijke vrijheid (Berkhof, 1973: 230). Ik denk zelfs dat het de eigenlijke reden is. Ook in de Middeleeuwen werden mensen door vreselijke rampen getroffen. De bevolking van Europa werd gedecimeerd. Ze gingen echter niet twijfelen aan Gods macht, maar aan zichzelf. Boetepredikers riepen mensen op zich te bekeren om aan de straf van God te ontkomen. En aan het begin van de Middeleeuwen had men de Hunnenhoofdman Attila die Europa teisterde al betiteld als de gesel Gods.

Het hoort dus typisch bij de moderne tijd om rampen niet meer te kunnen zien als Gods wil. En dat heeft te maken met de plaats die de mens zichzelf toedenkt in het bestel van de wereld. Die plaats wordt al maar groter. In de Verlichting is de mondige, zelf beslissende mens opgekomen. Bij dit mensbeeld past niet dat God alles regelt. We willen zelf zoveel mogelijk in de hand houden. Kenmerkend is de positie van Immanuel Kant, die God vooral ziet als postulaat van de ethiek (Kant, 1788:172-182): om ons handelen en denken richting te geven en niet meer als metafysische macht die de wereld bestuurt. ${ }^{6}$

4 Oettinger, 1977:170-181; Von Oettingen, 1900:109; Brunner, 1946:267-268; 1950:2425; Moltmann, 1985:99-100.

$5 \quad$ Zie over de vrijheid van de mens juist vanwege zijn verbondenheid met God vooral Brinkman (2000).

6 Vergelijk de these van Van Gennep (1989a:452; 1989b:21) dat God de wereld niet regeert door fysisch ingrijpen, maar door zijn gebod en belofte. Overigens heeft Van Gennep (1989a:194) eerder kritiek geoefend op Voltaire voor wie het bestaan van God nodig (is) om de deugd der mensen in stand te houden. Hij noemt dat zelfs blasfemie. 
Deze zelfverheffing van de mens weerspiegelt zich ook in de godsleer. God wordt steeds meer gemeten naar menselijke maatstaven. Aangezien wij ons niet kunnen voorstellen dat we duizenden mensen in kerken zouden ombrengen uit goede bedoelingen, kan God dat ook niet doen. Dat Gods weg een geheimenis is dat voor kleine mensen te groot en ondoorgrondelijk is, willen we niet langer aanvaarden. God moet inzichtelijk worden naar menselijke maatstaven.

God en mens zijn in de moderne tijd concurrenten geworden (Buskes, 1968). Waar wij handelen, kan God niet handelen. Enige tijd heeft men de spanning daarvan in de theologie nog kunnen weerstaan door de idee van de concursus (Berkouwer, 1950:151-189): aan al het menselijke handelen ligt Gods raad ten grondslag. Gods willen en ons willen gaan samen op. Maar daartegen verzet zich uiteindelijk de idee van de vrije, autonome menselijke beslissing. De mens heeft zijn eigen domein. Zo ontstaat een verkaveling van verantwoordelijkheden en mogelijkheden. God mag zich met een deel bezig houden en wij ook. Het probleem doet zich echter voor dat een verkaveling van vrijheid ook een verkaveling van macht is. En macht heeft de neiging zich uit te breiden. Dat is althans zo met menselijke macht. We nemen dus steeds meer in eigen hand. En wat we niet in de hand hebben, zoals de diepten van het heelal, nemen we op in ons eigen denken. Met onze wiskundige formules beheersen we het gans heelal, totdat Stephen Hawking of een van zijn collega's de laatste formule gevonden heeft. Dan kennen we de geest van God en zijn mens en God gelijk geworden (Hawking, 1988: 175). Anderen zijn nog wat voorzichtiger en willen God meer ruimte laten. De procestheologie ziet bijvoorbeeld God als het rijk van de mogelijkheden, die vervolgens door de wereld zelf gerealiseerd worden (Cob, 1966; zie ook Cobb \& Griffin, 1977). Anderen zien God als de samenhang (zeer toegespitst vinden we deze gedachte in Sharp, 1995) of de zingeving van de wereld (Nienhuis, 1995; Troelstra, 1995, sterk aanleunend tegen Van Gennep). Maar ook hier blijft de verkaveling. En uiteindelijk krijgt God daarin slechts de plek die wij mensen Hem toedenken. Vroeger of later komt dan het moment dat gezegd wordt: "Ik heb geen behoefte aan die hypothese". 7

\section{Verantwoordelijk}

De mens heeft zelf zijn lot in handen genomen en kan met zijn hoofd het heelal bevatten. Toch gaan er veel dingen mis in de wereld. Daarvoor moeten dus verantwoordelijken gezocht worden. We kunnen zeggen:

7 Radicaal is deze gedachte uitgewerkt door Philipse (1995), die stelt dat onder de condities van de Verlichting bewezen kan worden dat God niet bestaat. 
"De mens heeft dat gedaan". Maar als we eenmaal verantwoordelijkheden aan het verkavelen zijn, blijft dat doorgaan. De mens in het algemeen is veel te ongenuanceerd. Het zijn bepaalde mensen die dingen fout doen. Zelf wil ik het goede. Ik zou geen mensen verminken of vermoorden in Sierra Leone. Ik zou geen gaskamers oprichten. Het zijn anderen die dat doen. Zelfs als het in onze onmiddellijke omgeving gebeurt, kunnen we nog zeggen dat we er niet van geweten hebben, zoals zoveel Duitsers na de oorlog zeiden: "Wir haben es nicht gewusst". En als we er niet onderuit kunnen, dan betuigen we snel onze spijt, om te laten zien dat we nu in elk geval een ander mens zijn. $\mathrm{Na}$ de ondergang van het communisme in Oost-Europa zei men dat het druk was op de weg naar Damascus (verwijzend naar de geschiedenis van de bekering van Paulus in Handelingen 9).

We zien dus de paradoxale situatie dat aan de ene kant de mens zelf beslissen wil, maar tegelijk geen verantwoordelijkheid wil dragen voor de schuld van de wereld. Daardoor wordt de wereld opgesplitst in groepen van goeden en kwaden. Er worden vijandsbeelden gemaakt om onszelf aan de goede kant te houden. Juist in de dingen waar ergens in onszelf een antenne bestaat voor wat de ander fout doet, keren wij ons het hardste tegen die ander (vgl. Rom. 2:1). Het idee van de goede in vrijheid zelf kiezende mens, roept dus juist geweld (in alle variaties die geweld onder mensen kan hebben) op. Want ik laat mijn goedheid zien door de ander die de verkeerde keus gemaakt heeft, te bestrijden. Ik wil daarvoor in geen enkel opzicht verantwoordelijk zijn.

Juist daarin is God nu radicaal anders dan mensen. God stelt zich ten volle verantwoordelijk voor wat er in de wereld gebeurt. Er is in de Bijbel geen moment aarzeling dat God de wereld leidt. Hij stuurt de wolken (Psalm 147:8) en hij neigt de harten van de koningen (Spr. 21:1). Hij weet alles en als Hij het wil, kan hij zijn profeet bekendmaken wat de koning van Syrië spreekt in het binnenste van zijn slaapkamer (2 Kon. 6:12). God weet alles en God stuurt alles. God maakt er geen geheim van: "Inderdaad, Ik zit er achter". Er zijn geen diplomatieke formuleringen en geen ministeriële ontkenningen.

Dat geldt niet alleen voor de aangename dingen, maar ook als het donker lot zijn volk treft. Dat de God van Israël de Egyptische farao laat verdrinken (Ex. 14), kunnen we ons vanuit het standpunt van Israël nog voorstellen en we kunnen ons voorstellen dat ze dan heel hard gaan roepen: "Deze God is onze God". Maar ook als Israël zelf ondergaat, dan neemt God dat voluit voor zijn rekening. In de late koningentijd treffen rampen Israël. Er komen vijandige machten. Een aardbeving teistert het land. Het volk is er helemaal ontredderd door. In die situatie zegt de profeet Amos: "Geschiedt er een ramp in een stad, zonder dat de Here 
die bewerkt?" (Amos 3:6). Alles wat ons overkomen is, is vanwege onze zonden, die God bestraft.

Daar zit het eerste verschil tussen moderne discussies over de voorzienigheid en bijbelse motieven: in de moderne voorzienigheidsopvattingen moet God vriendelijk zijn. Hij moet voor ons zorgen. In de Bijbel is de weg van God vaak een dag des toorns (vgl. Amos 5:18-20). Het is daarom ook geen verborgen weg te noemen. Het is klip en klaar een reactie op de schuld van mensen. In tijden van nood kunnen we daarom voorzienigheid niet zomaar gebruiken om rustig te maken. Voorzienigheid maakt juist onrustig - en het meest als we al ongerust zijn. Want onze onrust leren we interpreteren als oordeel.

$\mathrm{Nu}$ is het donker lot niet altijd als oordeel op te vatten. Een klassiek voorbeeld daarvan is het boek Job. Niemand is zo godvrezend als Job (Job 1:8). Er is geen enkele reden Job zo te laten lijden. Dat zegt Job ook voortdurend. Maar ook hier neemt God verantwoordelijkheid. Inderdaad heeft Hij het leven van Job zo gestuurd. Hij neemt verantwoordelijkheid door eerst tegen Job te zeggen: denk jij dat jij met jouw kleine verstand Mij zou kunnen begrijpen? Moet jij Mij ter verantwoording roepen? (Job 38 e.v.). Ik ga in mijn weg al jouw oordelen verre te boven. Maar uiteindelijk gaat God nog verder in het op zich nemen van de verantwoordelijkheid. Het boek Job is te lezen als een juridisch proces. Uiteindelijk wordt Job in het gelijk gesteld, want hij krijgt alles dubbel terug (Job 42:10). Dat betekent volgens Israëlitisch recht dat het hem onrechtmatig ontnomen was (Ex. 22:9). God oordeelt dus over God dat Hij het bezit van Job onrechtmatig heeft genomen (zie hierover uitvoeriger Van de Beek, 1992: 91-92).

Nog verder gaat Trito-Jesaja. Israël heeft veel leed ervaren. Alle profeten hebben gezegd dat dat Gods oordeel over de zonde is. Trito-Jesaja heeft geen enkele behoefte die zonde te ontkennen. "Maar," vraagt hij dan, "waarom doet Gij ons dan van uw wegen dwalen?" (Jes. 63:17) (vgl. Van de Beek, 2000). U bent toch die machtige God voor wie alle volken niet meer zijn dan een stofje op een weegschaal (Jes. 40:15) en $U$ neigt toch de harten van de koningen, kunt $U$ dan onze harten niet neigen om $U$ te dienen? $U$ leidt toch onze gedachten en handelingen, waarom brengt (in een hif il, nota bene) $U$ ons dan op dwaalwegen? En ook dat wordt niet weersproken. Zelfs in de zonde van de mensen, gaat God zijn eigen weg, zoals Hij met opzet het hart van farao verhardde (Ex. 7:3).

God leidt dus alles. Zelfs de mens in zijn verharding en zonde wordt door Hem geleid. Maken we zo God niet tot auteur van de zonde? In de eerste plaats moeten we ons afvragen of dat theologisch verboden is. 
Want als het over het kwade en God gaat, komen er veel vragen op. Bijvoorbeeld de vraag of iets goed is omdat God het wil, of dat God het wil omdat het goed is. Is Gods wil niet zelf niet beslissend, niet onderworpen aan enig criterium dat boven Hem zou staan? En als Hij ons iets laat doen, dat Hij zonde noemt, dan is het ook zonde. Want wat zou boven dit oordeel van God uitgaan? Dat betekent ook dat als God zelf zich veroordeelt, en de volle verantwoordelijkheid neemt, Hij inderdaad schuldig is en verantwoordelijk. Wij denken vaak veel te aristotelisch over Gods leiding in de wereld, door te vragen naar oorzaken (en tenslotte naar laatste of eerste oorzaken), terwijl het in de theologie gaat om oordelen. Wie is er op aanspreekbaar en wie laat zich er op aanspreken?

Daar zit mijn spits in het denken over voorzienigheid en verantwoordelijkheid: God neemt de volle verantwoordelijkheid voor de wereld op zich en Hij laat zich daarop aanspreken.

Daarmee zitten we tegelijk in het hart van de christologie. God neemt de schuld der wereld op zich. En God neemt het lijden van de wereld op zich. Hij neemt onze dood op zich, die niet alleen een donker lot is, maar ook het loon op de zonde (Rom. 5:12; 6:23). Paulus zegt het in Galaten 3 heel scherp: Hij is een vloek geworden voor ons (Gal. 3:13). Want Hij is gekruisigd en volgens Gods eigen woord is een ieder die aan het hout hangt een vloek (Deut. 21:23). Zo is Jezus, de enige waarachtige God (Joh. 5:20), de Here der heerlijkheid (1 Kor. 2:8; Jak. 2:1), een vloek geworden. Het maakt daarbij niet uit of Hij schuldig of onschuldig gekruisigd is. Want het gaat niet om oorzaken, maar om oordelen. God heeft geoordeeld dat Hij de vloek draagt. Dat is zijn werkelijkheid. Zo is God in ons midden.

Vaak worden voorzienigheid en verzoening ver uit elkaar gehaald. Voorzienigheid heeft dan te maken met de leer van de schepping, als blijvende onderhouding van wat gevormd is en verzoening heeft te maken met het wegnemen van onze zonden. Als we echter denken vanuit de Schrift als Woord waarin Gods oordeel gesproken wordt, dan zijn voorzienigheid en verzoening keerzijden van dezelfde zaak. God neemt de volle verantwoordelijkheid op zich voor de verloren wereld en verenigt Zich daarom totaal met ons, in ons leven dat geoordeeld is als schuldig en ten dode gedoemd.

Daarmee komen we bij de klassieke Bijbeltekst waaraan het begrip "voorzienigheid" ontleend is: Genesis 22:8: "God zal zich zelf een lam ten brandoffer voorzien". In de vulgata staat hier providebit, waar het woord "providentia" van afgeleid is. Dat betekent: God zal zelf zorgen voor datgene waaraan we behoefte hebben. Dat lijkt de klassieke 
voorzienigheidsleer. Maar er zitten een aantal cruxen in deze tekst. In de eerste plaats gaat het niet over het algemene beleid van het bestaan, maar om de bijzondere roeping die Abraham ontving. Hij moet zijn zoon Izaäk gaan offeren. Abraham zegt dat God zelf moet zorgen voor het lam. 8 Dat kan uiteindelijk Izaäk zelf zijn. Dat is zelfs het meest waarschijnlijk, want dat was opgedragen. Dat maakt de voorzienigheid niet tot een bron van rust, maar van de hoogste onrust. God voorziet in de weg die Hij met de wereld gaat door ons te roepen en daarbij het dierbaarste te ontnemen. Zo is zijn bestuur. Bovendien vraagt Hij Izaäk als offer, dat te maken heeft met het geven van het leven voor God en omdat een mens daartoe nooit ten volle bereid is, ook altijd met schuld. God neemt genoegen met een lam, waar de mens zelf werd gevraagd. Daarom zit in het antwoord van Abraham al een belijdenis van de verzoening: God neemt met minder genoegen dan wij zouden moeten geven. Maar juist ditmaal wil Abraham wel alles geven. En nu voorziet de Here zelf, door de ram die straks in de struiken verward is (Gen. 22:13). God zelf geeft de ander, in plaats van Izaäk - of ook in plaats van Zichzelf, door Zelf te erkennen dat Hij van Abraham niet mag vragen wat Hij vroeg. God oordeelt zelf dat de roeping voor Abraham teveel gevraagd was, ook als Abraham die weg tot het einde bereid was te gaan. God zelf voorziet in het offerdier, waarin God en mens met elkaar verder kunnen. Deze voorzienigheid is verzoening. Het is goed nog te letten op de verschuiving van de dieren: Abraham spreekt over een lam, God geeft een ram. Blijkbaar zijn ons offer en het offer van God niet identiek. Tegelijk blijft er daardoor iets open van de opmerking van Abraham. God voorziet op andere wijze, maar waar blijft het lam, dat Izaäk moet vervangen? Vanuit het evangelie klinkt door: "Zie, het lam van God dat de zonde der wereld draagt" (Joh. 1:29).

De kerntekst over de voorzienigheid loopt uit op het offer der verzoening. Dat is niet achteraf aan Genesis opgelegd, maar is in de tekst al begrepen. Want staat er: "Op de berg des Heren zal erin voorzien worden" (Gen. 22:14). Op de berg des Heren, in Jeruzalem, worden de offers gebracht. Daar ontmoet Israël zijn God in het heiligdom, elk jaar opnieuw beginnend met de Grote Verzoendag. Zo mag je het heiligdom binnengaan om God te ontmoeten. Dan komen alle vragen over het beleid van het bestaan in een ander licht. Het is de gang die Psalm 73 gaat, een lied van een priester in de tempel. Die begint met de vraag waarom het de goddelozen goed gaat in de wereld en de rechtvaardigen lijden. Gods bestuur klopt niet en soms denkt hij erover om ook maar een goddeloze

8 God zal zelf voorzien victimam holocausti, vertaalt de Vulgata. Na de gebeurtenissen van de Tweede Wereldoorlog krijgt deze zin een nog zwaardere betekenis dan die al had. Vgl. ook voetnoot 14. 
te worden (vs.10, 15). Alleen zijn trouw aan Gods kinderen bewaart hem ervoor (vs. 15). Hij wil zijn medegelovigen niet in de steek laten. ${ }^{9}$ Maar hij begrijpt er niets van. Totdat hij in Gods heiligdom ingaat en op het einde van de goddelozen lette. Op een gegeven moment is het met hen afgelopen. En dan zinken ze voor altijd in de verwoesting (vs. 17-19). Niets blijft er van hen over. Maar mij aangaande, het is mij goed nabij God te wezen (vs. 28). Zelfs als dan je hart en je vlees bezwijken, maakt niet meer uit (vs. 26). De nabijheid bij God die de volle verantwoordelijkheid neemt voor ons bestaan en dus voor onze schuld, door in zichzelf een offer te voorzien, is het enige wat van belang is. Zijn goedertierenheid is beter dan het leven. Nabij deze God te zijn en zijn roeping te volgen, de weg gaan waar Hij ons brengt, tot in het offer van onszelf, is ons genoeg.

\section{Zorgeloosheid of verantwoordelijkheid?}

Op deze wijze worden voorzienigheid en verzoening ten nauwste verbonden. De Nederlandse theoloog Noordmans heeft er in een bespreking van de Catechismus reeds op gewezen hoe belangrijk het is om christologie en voorzienigheid nauw op elkaar betrokken te houden (Noordmans, 1979:460-470). Hij maakt dat duidelijk vanuit Mattheus 6:25-34: Wees niet bezorgd. Kerntekst is voor Noordmans vers 33: "Zoekt eerst het koninkrijk van God en zijn gerechtigheid". We hebben de neiging om alleen het andere deel van de pericoop te horen: "Wees niet bezorgd over uw kleding en voedsel". Dat klinkt rustgevend. Want God zorgt voor ons. Noordmans laat zien hoe de beide delen samenhangen en dat de roep van het koninkrijk bepalend is voor ons omgaan met voedsel en kleding. Dat is het wat Jezus zegt. En "wanneer Jezus dat doet, dan is het niet zijn bedoeling om zorgen te stillen, maar om zorgen te wekken" (Noordmans, 1979:460). Want leef je in het koninkrijk? Zijn we inderdaad bereid deze God en zijn roeping te volgen en Hem tot in het offer van onszelf nabij te zijn?

Voorzienigheid heeft dus niets met berusting te maken. Hetzelfde geldt trouwens ook voor de verzoening. Net zoals we bij de voorzienigheid kunnen zeggen dat God wel voor ons zorgen zal en wij dus onbezorgd kunnen zijn, zo kunnen we bij de verzoening denken dat God onze zonden wel vergeeft en wij ons daarover dus geen zorgen meer hoeven te maken. Als het echter om werkelijke verzoening gaat, dan gaat het om gemeenschap met God. Het is die God die volle verantwoordelijkheid voor ons leven neemt. En als deze God onze God is, dan nemen wij dus ook volle verantwoordelijkheid voor Hem, we aanvaarden zijn weg, niet uit de samenkomst van de gemeente. 
berustend, maar actief. Wij aanvaarden net als Hij volle verantwoordelijkheid voor de wereld. Die gaat ons aan. Het is onze wereld, omdat het de wereld van onze Vader is. Zo word ik zelf verantwoordelijk voor het lijden wat er plaats vindt. Vroeger werd vaak de term "eenswillens met God worden" gebruikt. Daarmee werd bedoeld dat wij leren instemmen met de weg die God in ons leven gaat, ook als dat een moeilijke weg is. Eenswillens worden reikt echter verder: het is ook leren instemmen met de weg die God in de wereld gaat, bijvoorbeeld in Sierra Leone. Zo legt juist het aanvaarden van de weg van God een onnoemelijk zware verantwoordelijkheid op ons. Het is de weg van mijn hemelse Vader. Dat wil niet zeggen dat je daarom maar accepteren moet wat er allemaal gebeurt. Dat zouden we wel moeten doen als God een abstracte eerste oorzaak was. God wordt dan identiek met het lot en wat God doet dat is noodzakelijk en noodzakelijkerwijze goed. Als God echter verantwoordelijkheid neemt, dan neemt Hij zoals bij Job ook de schuld op zich en herstelt Jobs leven. Als wij een zijn met God in de verzoening in Christus, nemen wij daarom ook de schuld der wereld op ons, delend in zijn oordeel, delend in zijn lijden, delend in het leven dat Hij door de dood heen de mensen schenkt.

Dat is bedoeld met: "Zoekt eerst het koninkrijk van God en zijn gerechtigheid". Het betekent dat we het koningschap van God aanvaarden en daarnaar leven. Dat reikt heel wat verder dan het houden van vastgestelde wetsregels. Onze gerechtigheid moet overvloediger zijn dan die van de Farizeeën (Matt. 5:20). Het is het leven waarin je je leven geeft voor je vijanden, omdat hun leven jou aangaat. Het is een leven waarin alles van je gevraagd wordt, waarin je zelf gevraagd wordt om niet meer van je zelf te zijn, maar van Christus en als je van Christus bent, dan ben je van God. Dat wil zeggen: van die God die zijn leven gaf omdat Hij de verantwoordelijkheid voor de wereld op zich nam.

Noordmans $(1979: 442,467)$ zegt terecht dat het goed is dat de Catechismus de geloofsbelijdenis behandelt, met zijn trinitarische structuur. Dat behoedt ons voor een eenzijdige gerichtheid op de soteriologie en bewaart ons zo voor een goedkope genade. Noordmans heeft echter de indruk dat de Catechismus in zondag 10 toch beide te ver uit elkaar houdt. We hebben een goed toevoorzicht op God, die voor alles zorgen zal, maar de spanning van het koninkrijk ontbreekt in deze zondag. Misschien ligt het niet zozeer aan de Catechismus, als wel aan de latere interpretatie daarvan in de gereformeerde en neo-calvinistische scholastiek, waarin de natuur en de algemene genade steeds meer een zelfstandige plaats krijgen.10 En dat kan in het christelijk geloof nooit het

10 Men denke vooral aan de drie delen van Abraham Kuyper over De gemeene gratie (Kuyper, z.j.). 
geval zijn. Daarin krijgt de schepping en onderhouding zijn betekenis vanuit het kruis. En omgekeerd krijgt het kruis zijn betekenis uit de schepping en de dingen van de dag.

Dat laatste is door Noordmans minder scherp in beeld gebracht dan het eerste. Wie dat wel deed was de kerkvader Irenaeus. Irenaeus legt er de volle nadruk op dat Christus gekomen is tot het zijne. Hij kwam niet in een wereld die Hem vreemd was, maar in zijn eigen wereld (Irenaeus, Adversus Haereses IV, 38-39). Dat is niet een ideale wereld, maar deze concrete aarde met zijn moeite, pijn en schuld. Het is de wereld van Sierra Leone en van de oude zwarte vrouw in de Karoo, die als conclusie van haar leven zei: "Ek is so moeg, Basie".11 De wereld van deze vermoeienis is Gods wereld. Irenaeus denkt niet vanuit de staat der rechtheid als de echte schepping en de huidige wereld als minderwaardig. Elke zweem van Marcionitisme bant hij uit. Deze wereld waarin we leven, is niet minderwaardig, ook niet de wereld die wij in het nieuws op de televisie zien. Want deze wereld heeft God geschapen en deze wereld heeft Hij zo lief dat Hij gekomen is tot het zijne, om de volle verantwoordelijkheid daarvoor te dragen, tot op het kruis toe. De wereld met haar kruis, haar lijden en haar vervloeking, is de wereld met wie God helemaal een is.

Voor Irenaeus kun je God niet diep genoeg in het vlees trekken. Tot in de diepste nood van schuld en dood is Hij er en onttrekt Hij zich niet aan ons menselijke bestaan. Dat is Gods koningschap, het koningschap van de koning der Joden (Matt. 27:37; Mark. 15:26; Luk. 23:38; Joh. 19:19). Daar staat de naamplaat waar God kantoor houdt.

Willen wij medewerkers zijn van deze firma? Willen wij ten kantore gaan en onze taak opnemen waar deze God koning is? Willen wij het koningschap van God aanvaarden? Jezus zegt het nog sterker: "Zoekt eerst het koninkrijk van God en zijn gerechtigheid". Zoekt eerst het kruis. Daarmee is niet het kruis van de goedkope genade bedoeld. Het is ook niet het kruis van een romantische film. Het is het kruis van de gerechtigheid. Gerechtigheid betekent in het koninkrijk van God dat je alles geeft. In Jeruzalem vind je bij de westelijke muur van de tempel een kist waarin je gaven voor de armen kunt geven. Daarop staat niet "aalmoezen", maar tsedaqah - "gerechtigheid".12 Gaven voor de armen zijn geen gunst, maar een recht van de arme. Zo ver zijn we in de regel

11 Ook al is het nu niet correct meer om "Basie" te gebruiken, tock blijven mensen dat doen. Het duurt lang voordat onderdrukking ook uit hoofden en harten van mensen verdwenen is. Ook dat behoort bij de vermoeienis van deze wereld.

12 Dezelfde betekenis van "gerechtigheid" vinden we in Matt. 6:1. 
niet in de kerk. Maar Jezus gaat nog verder. Als onze gerechtigheid groter moet zijn dan die van de farizeeën betekent het dat we niet slechts klinkende munt even, maar dat we heel ons leven geven.

Nu komt ook de tweede helft van de zin uit Mattheus 6 in een ander licht. Zoekt eerst het koninkrijk van God en zijn gerechtigheid en al deze dingen zullen $u$ toegeworpen worden. Meestal wordt het zo geïnterpreteerd dat als je eerst maar kind van God bent, God wel voor je leven zorgen zal. Daarover hoef je je dan niet meer te bekommeren. Maar de kritische zin over het koninkrijk krijgt pas zijn volle betekenis in het concrete van "al deze dingen". Al deze dingen van voedsel en kleding, de dingen van de dag, staan niet naast het koninkrijk van God, ze zijn ook niet iets extra, maar ze zijn er de expressie van.

Hoe kan ik het koninkrijk van God zoeken en zijn gerechtigheid? Dat is niet een abstract geloof, maar krijgt gestalte in concrete daden. Daarvoor zijn voedsel en kleding de instrumenten. Als men je hemd wil nemen, geef dan je mantel daarbij (Matt. 5:40). Daarvoor krijg je dus mantels en rokken. Daarvoor krijg je voeten, om twee mijl mee te gaan met wie je vraagt om een mijl (Matt. 5:41). Dat maakt het spreken over "al die dingen" tot een nieuwe onrust. Het wordt mij niet gegeven om ze voor me zelf te houden, maar om er God mee te dienen, zoals in het klassieke gereformeerde trouwformulier gezegd wordt dat een man moet werken, om iets te hebben om aan de armen mee te delen (vgl. ook Efeze 4:28).

Dat is moeilijk. Je weet eigenlijk nooit goed hoe je hierin handelen moet. Je wordt steeds weer teruggeworpen op je eigen schuld, omdat je steeds weer vraagt hoe ver je moet gaan.13 Maar het koninkrijk van God is onbegrensd. Je wordt zelf gevraagd, totaal. En daarmee weten we in de wereld niet om te gaan. We weten niet hoe we moeten omgaan met onze goederen, vooral niet als we er veel hebben, zoals de rijke jongeling (Matt. 19:16-26). Nu wordt ineens wat onze winst was, onze zorg. Wat onze rust was, wordt onze onrust. Je zult maar gezegend zijn met veel gaven. Want hoe meer je hebt, hoe minder je raad weet, hoe je er mee om moet gaan. Een sober, zelfs een arm leven kan zo plotseling een zegen worden. Als we het zelf gaan kiezen, als een kluizenaar, kan het even onverwacht weer een bezit worden. Maar de geestelijke rijkdom die je daarmee verwerft, maakt je nog meer verantwoordelijk, zodat de dag komt dat je terug verlangt naar de dag dat je materieel rijk was. Toen was je rijkdom nog je armoede die je onrust gaf, in de kluis van de heremiet ben je zelf tot armoede in je geestelijke rijkdom.

13 Vgl. de vraag van de wetgeleerde: “Wie is mijn naaste?” in Luk. 10:29. 
Al deze dingen worden u toegeworpen. Ze worden je toegeworpen voor je onrust. Ze worden je toegeworpen als een kruis om te dragen. En hoe rijker je bent, des te zwaarder je kruis. En zelfs dat kan nog een bezit worden. De kritiek van het koninkrijk houdt nooit op. Een lied in het Nederlandse Liedboek voor de Kerken zegt: "Waarom moest ik uw stem verstaan - waarom die onrust in mijn hart?" (Gez. 484:1). Eigenlijk is deze God ons te veel. "Gij zijt een mens te veel", zegt een ander lied (Gez. 491:2). God vraagt te veel van mensen, omdat Hij mens geworden is. Omdat God zo ver in het vlees gekomen is dat Hij stierf in verantwoordelijkheid voor de wereld aan het kruis en zo ons ons leven toonde ${ }^{14}$ als de dood, zouden we wensen dat deze mens er nooit was geweest. Waarom is God niet gewoon God de Heer in het glorielicht gebleven, zoals het goden betaamt? Hij is een mens te veel op aarde. Daarom verbergen wij ons aangezicht voor Hem (Jes. 53:3): we willen Hem niet zien.

\section{Zien}

Met "zien" zijn we weer terug bij Genesis. God zal zelf zien (22:8). We hebben het nu over het zien van mensen. Genesis heeft die beide al eerder met elkaar in verband gebracht, in hoofdstuk 16, toen Hagar zei: "Heb ik ook gezien naar Hem die naar mij heeft gezien?" (vs. 13). God heeft haar gezien, maar heeft zij Hem wel gezien? Hebben wij deze God, die zelf een lam ten brandoffer ziet, wel gezien? Hagar heeft Hem leren zien. Het gebeurde bij de put Lachai Roi: van de Levende van mijn zien (16:14). Het is niet uit te maken of "mijn" een subjectivus of een objectivus is. Dat maakt ook niet uit: waar twee elkaar zien, is zien en gezien worden een, net als kennen en gekend worden (1 Kor. 13:12). Hagar heeft Hem gezien, want Hij heeft Hagar gezien. Dat wil niet zeggen dat nu de problemen opgelost zijn. Hagar gaat nu de weg van het kruis. De slavin moet terug naar haar bazin (Gen. 16:9). En daar is geen medelijden met een zwangere vrouw die, uit de woestijn komend, met haar lijf zegt: "Ek is so moeg, Miesies". 15 Ze wordt vernederd door Sara om straks opnieuw de woestijn in te moeten, nu niet de vrijheid tegemoet, maar als een uitgedrevene (Gen. 21:10), als de zondebok op de grote verzoendag (Lev. 16:21 e.v.). Dat was niet alleen de wil van Sara, maar ook de wil van de Here (Gen. 21:12). Zo heeft de Here naar haar gezien. En zo heeft Hagar Hem gezien: de God die alles van je vraagt en die je totale verantwoordelijkheid laat nemen, ook de bittere

14 Liedboek der Kerken, Gezang 193:1: "O wereld, zie uw leven, hoog aan het kruis geheven". 
verantwoordelijkheid van een slaaf. Dat is de gerechtigheid die verder reikt.

In Genesis 21 komt het zien terug. Hagar is opnieuw in de woestijn. Zij heeft alles gegeven omdat God haar zag. Ze zag wat ze voor Hem moest doen. Ze is als een zondebok in de woestijn, om te sterven van ellende en dorst. Maar er is er een bij haar: haar kind, Ismaël. Zij is op een afstand gaan zitten, want ze kan de jongen niet zien in zijn sterven (Gen. 21:16). Dat is als moeder ook niet om aan te zien. In onze machteloosheid sluiten we onze ogen voor de ander, en het meest voor de ander die ons het meest raakt. We willen het niet zien. Tot de Here haar ogen opent en zij ziet. Dan ziet zij het water des levens, voor haar en haar zoon (Gen. 21:19). De Here heeft er in voorzien.

Paulus schrijft in Filippenzen 2:12: "Bewerk uw redding met vrezen en beven, want het is God die in u werkt beide het willen en het werken". Omdat God ons ziet, leren wij ook zien. Maar al dat spreken over zien, staat in het teken van het offer: het offer van de zoon, van Hagar, van Abraham. Beiden zagen pas op het moment dat hun zoon stervende was. Het zien van het water en de ram werd hun behoud. Maar het is bij gelijkenis opstanding uit de dood, zegt Hebreeën (11:19). En sommige mensen leren nooit zien, zoals farao in Egypte wiens hart werd verstokt. Hij verloor zijn zoon (Ex. 12:29), omdat hij niet zag. De Egyptische slavin (Gen. 16:1) zag, terwijl de Egyptische koning niet zag. ${ }^{16}$

Voorzienigheid is zien. Het is zien van God en zien van ons. Het is samen zien in de verzoening van Christus. Het is samen dragen van de verantwoordelijkheid voor de wereld, als arme Hagar en als rijke Abraham. Abraham leerde zien op Moria. Hagar was toen al heengegaan met haar zoon - met zijn zoon. Heeft Abraham hem ooit weer gezien? In elk geval heeft Ismaël Abraham gezien, om hem de eer te bewijzen die hem toekomt bij de begrafenis, toen Ismaël en Izaäk hem begroeven (Gen. 25:9)17 - bij Sara. Heeft Sara ooit gezien?

16 Er is een opvallend verschil tussen Ex. 11:5 en Ex. 12:29. In beide verzen wordt gesproken over de dood van de zoon van farao. Maar de tegenpool is in beide verzen verschillend. Het oordeel wordt aangekondigd over de slavin bij de molen, maar het wordt voltrokken aan de gevangene. Deze gevangene brengt Israël zelf in gedachten in hun gevangenschap. Ze mogen gaan, maar heeft Israël al niet zijn zoon, zichzelf verloren? Vgl. Ex. 4:18-26. Er is blijkbaar een sterke dialektiek in oordeel en bevrijding zoals aankondiging en voltrekking niet identiek zijn. Het oordeel blijft altijd het concrete oordeel van God en is nooit een vast te leggen gegeven. Vgl. ook Ezech. 18.

17 Opvallend is dat juist Izaäk gaat wonen bij de put Lachai-Roi (Gen. 24:62; 25:11). Maar hij eindigt, wonend bij de bron van het zien, als een blinde (Gen. 27:1). 
Kernwoord van zorg en verantwoordelijkheid is zien. Daarbij hoef je niet te denken aan verkaveling van bevoegdheden en taken. Zien kun je samen, tegelijkertijd. Mijn zien van de nood van de wereld komt niet in mindering op het zien van een ander. Integendeel, we kunnen elkaar de ogen openen om samen beter te zien. Dat begint met samen horen naar de stem van Gods bode, naar de Schrift, om geopende ogen te krijgen. Dat is geen houding van afwachten, want het gaat om zaken van leven en dood, van zien of niet zien. Juist omdat we het einde niet bereikt hebben en zelf ten volle leven in deze wereld bidden we steeds weer: "Dat ik ziende mag worden".18

Wat is voorzienigheid? Dat God mij ziet; dat ik Hem zie; dat ik de ogen geopend heb om de ander te zien; dat God het lam ten offer ziet en dat ik de ram zie - tenslotte dat op de berg des Heren gezien wordt, in Jeruzalem, waar onze Here gekruisigd is.

\section{Bibliografie}

BERKHOF, H. 1973. Christelijk geloof: een inleiding tot de geloofsleer. Nijkerk : Callenbach.

BERKOUWER, G.C. 1950. De voorzienigheid Gods. Dogmatische Studiën. Kampen : Kok.

BRINKMAN, M.E. 2000. Het drama van de menselijke vrijheid: de ambivalente rol van het menselijke vrijheidsbegrip in de westerse cultuur. Zoetermeer : Meinema.

BRUNNER, E. 1946. Die christliche Lehre von Gott: Dogmatik 1. Zürich : ZwingliVerlag.

BRUNNER, E. 1950. Die christliche Lehre von Schöpfumg und Erlösung: Dogmatik 2. Zürich : Zwingli-Verlag.

BUSKES, J.J. 1968. God en mens als concurrenten. Carillon-paperbackreeks 15. Amsterdam : Ten Have.

COBB, J.B. 1966. A Christian natural theology based on the thought of Alfred North Whitehead. London : Luttenworth.

COBB, J.B. \& GRIFFIN, D.R. 1977. Process theology: an introductory exposition. Philadelphia : Westminster.

HAWKING, S. 1988. A brief history of time: from the Big Bang to Black Holes. Toronto : Bantam Books.

KANT, I. 1788. Kritik der praktischen Vernunft. Riga : Hartknoch. (Hsgb. R. Schmidt, Wiesbaden : VMA-Verlag. 1928.)

KUSHNER, H.S. 1987. Als 't kwaad goede mensen treft. Baarn : Ten Have.

KUYPER, A. z.j. De gemeene gratie 1-3. Kampen : Kok.

LEIBNIZ, G.W. 1710. Essais de théodicée: sur le bonté de Dieu, la liberté de l'homme et l'origine du mal. Amsterdam : Francois. (Paris : GarnierFlammarion. 1969.)

MOLTMANN, J. 1985. Gott in der Schöpfung: Ökologische Schöpfungslehre. München : Kaiser.

Luk. 18:41. Vergelijk de ambiguïteit van zien en blind zijn in Joh. 9. 
NIENHUIS, G. 1995. Toeval en voorzienigheid. (In Van de Beek, A., red. Lichtgeraakt: wetenschapsbeoefenaren over de relatie van hun gelovig christen-zijn en hun werk. Nijkerk : Callenbach. p. 36-50.)

NOORDMANS, O. 1979. Het Koninkrijk der hemelen. (In Verzamelde Werken 2. Kampen : Kok. p. 433-550.)

OETTINGER, F.C. 1977. Die Lehrtafel des Prinzessin Antonia 1. (Hrsg. R. Breymayer \& F. Häussermann.) Berlin/New York : De Gruyter.

PHILIPSE, H. 1995. Atheïstisch manifest: drie wijsgerige opstellen over godsdient en moraal. Amsterdam : Prometheus.

SHARP, K. 1995. God as the World-as-a-Whole. (In Gregersen, N.H., Parsons, M.W.S. \& Wasserman, C., eds. The concept of nature in science and theology. Part I. Studies in Science and Theology (SSTh), vol. 3. Geneva : Labor et Fides. p. 153-157.)

TROELSTRA, A.S. 1995. Over geloof en natuurwetenschap. (In Van de Beek, A., red. Lichtgeraakt: wetenschapsbeoefenaren over de relatie van hun gelovig christen-zijn en hun werk. Nijkerk : Callenbach. p. 26-35.)

VAN DE BEEK, A. 1992. Rechtvaardiger dan God: gedachten bij het boek Job. Nijkerk : Callenbach.

VAN DE BEEK, A. 2000. Doet God dwalen? Bijbelstudie over Jesaja 63:17. Kontekstueel, 15(1):4-6.

VAN GENNEP, F.O. 1989a. De terugkeer van de verloren vader: een theologisch essay over vaderschap en macht. Baarn : Ten Have.

VAN GENNEP, F.O. 1989b. Het is beslist. (In Van Gennep, F.O. e.a. Waarlijk opgestaan: een discussie over de opstanding van Jezus Christus. Baarn : Ten Have.)

VAN RULER, A.A. 1972. God en de chaos. (In Theologisch Werk 5. Nijkerk : Callenbach. p. 32-45.)

VON OETTINGEN, A. 1900. Lutherische Dogmatik 2: System der christlichen Heilswahrheit 1: Die Heilsbedingungen. München : Kaiser.

\section{Kernbegrippen:}

bezorgdheid

offer

verantwoordelijkheid

verzoening

voorzienigheid

\section{Key concepts:}

atonement

providence

responsibility

sacrifice

worry 